\title{
Sikap Positif, Kreatif, dan Optimisme Terhadap Prestasi Belajar Mata Kuliah PAUD4504 Mahasiswa PG PAUD di Unit Program Belajar Jarak Jauh (UPBJJ) UT Makassar
}

\author{
Kusmaladewi \\ Manajemen Pendidikan Universitas Terbuka, Makassar \\ Email: kusmaladewi@ecampus.ut.ac.id
}

\begin{abstract}
Abstrak. Penelitian ini bertujuan untuk mengetahui apakah sikap positif, optimis, dan kreatif berpengaruh terhadap prestasi belajar mata kuliah PAUD4504 mahasiswa PG PAUD di UPBJJ UT Makassar, dan apakah sikap pikiran positif, optimisme, dan kreatif berpengaruh secara bersama-sama terhadap prestasi belajar PAUD4504 mahasiswa PG PAUD di UPBJJ UT Makassar. Data dianalisis dengan program IBM SPSS 21. Hasil penelitian menunjukkan bahwa (1) terdapat 39,6\% sikap positif, 36,8\% \% sikap optimisme, dan $34,6 \%$ siakp kreatif, (2) terdapat pengaruh positif yang signifikan antara siakp positif dengan prestasi belajar mata kuliah PAUD4504 (Y), koefisien korelasi sebesar 0,629a dengan nilai signifikansi 0,000b lebih kecil dari probabilitas $<0,05$ (3) terdapat pengaruh positif yang signifikan antara sikap optimisme dengan prestasi belajar mata kuliah PAUD4504 (Y), koefisien korelasi sebesar 0,607a dengan nilai signifikansi $0,000 \mathrm{~b}$ lebih kecil dari probabilitas $<0,05$ (4) terdapat pengaruh positif yang signifikan antara sikap kreatif dengan prestasi belajar mata kuliah PAUD4504 (Y), koefisien korelasi sebesar 0,589a dengan nilai signifikansi 0,000b lebih kecil dari probabilitas < 0,05 (5) terdapat pengaruh positif yang signifikan antara sikap positif (X1), sikap optimisme, (X2) dan sikap kreatif (X3), dengan prestasi belajar mata kuliah PAUD4504 (Y) mahasiswa Universitas Terbuka UPBJJ Makassar koefisien korelasi sebesar 0,725a.
\end{abstract}

Kata Kunci: Sikap Positif; Optimis; Kreatif; Prestasi Belajar

\begin{abstract}
This study aims to determine whether a positive, optimistic, and creative attitude influences the learning achievement of PAUD4504 subjects in PAUD PAUD students at UPBJJ UT Makassar, and whether positive, optimistic, and creative attitudes influence together towards PAUD4504 PAUD students' learning achievement. at UPBJJ UT Makassar. The data was analyzed with the IBM SPSS 21 program. The results showed that (1) there were $39.6 \%$ positive attitudes, $36.8 \% \%$ optimism attitudes, and $34.6 \%$ creative minds, (2) there were significant positive influences between positive attitudes with the learning achievement of PAUD4504 (Y) course, the correlation coefficient of $0.629 \mathrm{a}$ with a significance value of $0.000 \mathrm{~b}$ is smaller than the probability $<0.05$ (3) there is a significant positive effect between optimism attitude and learning achievement of PAUD4504 (Y), the coefficient correlation of $0.607 \mathrm{a}$ with a significance value of $0.000 \mathrm{~b}$ is smaller than the probability $<0.05$ (4) there is a significant positive effect between creative attitude and learning achievement of PAUD4504 (Y), the correlation coefficient of $0.589 \mathrm{a}$ with a significance value of $0,000 \mathrm{~b}$ is smaller of probability $<0.05(5)$ there is a significant positive effect between positive attitude (X1), optimism attitude, (X2) and creative attitude (X3), and learning achievement of PAUD4504 course ( Y) UPBJJ Makassar Open University students correlation coefficient of $0.725 \mathrm{a}$.
\end{abstract}

Keywords: Positive Attitude; Optimistic; Creative; Learning Achievement

\section{PENDAHULUAN}

Sikap positif, kreatif, dan optimisme merupakan multisikap mental yang melibatkan proses memasukan pikiran-pikiran, kata-kata, dan gambaran-gambaran yang konstruktif bagi perkembangan dan target penyelesaian studi yang diharapkan. Sikap pikiran positif berusaha menyadari masalah secara seimbang 
sehingga tetap termotivasi, mampu bertindak, dan merasa senang menyelesaikan masalah yang dihadapi. Sikap pikiran positif membatu untuk menyadari perasaan, pemikiran, dan keyakinan untuk memperoleh suatu kesuksesan. Orang yang positif mencapai lebih baik daripada pemikir negatif. Dengan sikap pikiran akan bermanfaat baik diri sendiri maupun kepada orang lain (Quilliam S, 2007: 7). Seorang anak dapat berkembang dengan baik dalamlingkungan yang memberinya kesempatan kepada anak untuk mengoptimalkan perkembangan baik dari segi fisik, mental, serta memenuhi kebutuhan kognitif, afektifi, psikomotorik (Maemunah, Herman, \& Rahmatullah, 2018).

Sikap kreatif lebih memudahkan atau menciptakan hal-hal yang mungkin bisa berdampak positif terhadap kesenangan, kemudahan, atau manfaat bekerja. Sikap kreatif sangat mendukung meningkatkan kepuasan dalam bekerja. Semakin kreatif, semakin mudah menemukan atau menciptakan kepuasan dalam bekerja (Sun, 2013). Sikap optimisme membuat apa yang orang lain anggap sebagai hal mustahil tetapi bisa diwujudkan menjadi kenyataan. Optimisme lahir dari dalam hati individu untuk menghadapi setiap permasalahan yang terjadi. Optimisme sebuah kekuatan terbesar manusia. Optimisme memberikan energy dan arah pada tujuan yang lahir sebelum aksi nyata. Orang optimis biasanya lebih mungkin bisa mencapai apa yang ia inginkan daripada orang pesimis (Nugroho D. 2017: 61-63).

Mata kuliah PAUD4504 ini adalah mata kuliah berpraktek yang menghendaki mahasiswa meneliti secara sederhana dan menganalisis kegiatan pengembangan anak usia di lembaga PAUD dengan menggunakan teknik observasi, wawancara, dan pengumpulan dokumen yang berkaitan dengan kegiatan PAUD, yaitu kelompok bermain (KB), tempat penitipan anak (TPA) dan taman kanak-kanak (TK). Setiap selesai meneliti di satu lembaga PAUD, mahasiswa diminta membuat laporan dan analisis kegiatan pengembangan di lembaga PAUD tersebut dengan menggunakan teori-teori yang pernah dipelajarinya dari mata kuliah yang telah diambil sebelumnya. Esensi dan karakteristik mata kuliah PAUD4504 mengindikasikan bahwa mata kuliah sulit karena membutuhkan pengetahuan (knowledge), keterampilan (skills), dan perilaku (attitude).
Beberapa hasil penelitian terkait dengan sikap pikiran positif, kreatif, dan optimistik dengan signifikasi prestasi belajar. Sargih Sahat (2007) menyimpulkan bahwa sikap positif siswa terhadap matematika dapat meningkatkan hasil belajar siswa. Hartati Leny (2013) menyebutkan bahwa hasil belajar matematika siswa yang memiliki sikap positif pada mata pelajaran matematika lebih tinggi daripada siswa yang memiliki sikap negatif. Farida Nurul (2014) menyebutkan bahwa prestasi belajar matematika peserta didik yang memiliki sikap kreatif yang tinggi lebih baik dibandingkan peserta didik yang memiliki sikap kreatif sedang maupun rendah dan prestasi belajar memiliki sikap kreatif sedang lebih baik dibandingkan peserta didik yang memiliki sikap kreatif rendah. Kurniati Lenny\&Fachruddin AU (2018) menyebutkan optimisme pemecahan masalah matematika siswa mempunyai hubungan positif dan signifikan. Optimisme mempengaruhi kemampuan pemecahan masalah matematika siswa sebesar $63 \%$.

Uraian latar belakang di atas menginspirasi penulis untuk melakukan kajian emprik dengan fokus apakah sikap pikiran positif, kreatif, dan sikap optimistis berpengaruh terhadap prestasi belajar mata kuiah PAUD4504 PG PAUD mahasiswa di UPBJJ UT Makassar.

\section{METODE PENELITIAN \\ Desain Penelitian}

Desain penelitian kuantitatif ini dapat divisualisasikan sebagai berikut:

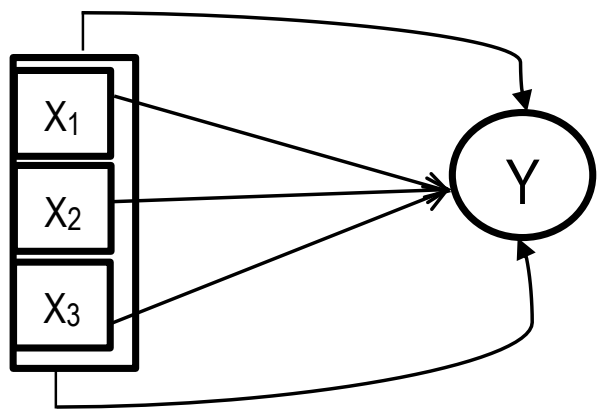

Keterangan:

$$
\begin{array}{ll}
\mathrm{X} & \text { : Variabel Bebas } \\
\mathrm{X}_{1} & \text { : Sikap Pikiran Positif } \\
\mathrm{X}_{2} & \text { : Sikap Kreatif } \\
\mathrm{X}_{3} & \text { : Sikap Optimis } \\
\mathrm{Y} & \text { : Prestasi Belajar berfungsi sebagai } \\
& \text { variabel terikat } \\
\longrightarrow & \text { : Pengaruh per variable ke Y }
\end{array}
$$




\section{Variabel Penelitian}

Dalam penelitian ini ada tiga variable bebas, yaitu variabel sikap pikiran positif $\left(\mathrm{X}_{1}\right)$. sikap kreatif $\left(\mathrm{X}_{2}\right)$, dan sikap optimis $\left(\mathrm{X}_{3}\right)$ sedangkan variabel terikat, yaitu prestasi belajar mata kuliah PAUD4504 ( variable Y).

Definisi Operasional Variabel

1. Prestasi belajar adalah skor nilai akhir mata kuliah PAUD4504 yang bersumber dari nilai partisipasi, laporan di TK, di KB, dan di TPA mahasiswa PG PAUD Universitas Terbuka di UPBJJ Makassar

2. Sikap positif adalah skor yang diperoleh dari mahasiswa PG PAUD Universitas Terbuka di UPBJJ Makassar berupa: cara penguatan pandangan, pengaruh orang lain, moment tertentu, menghadapi masalah yang dikemas dalam bentuk kuesioner

3. Sikap kreatif adalah skor yang diperoleh dari mahasiswa PG PAUD Universitas Terbuka di UPBJJ Makassar berupa: rasa ingin tahu, imajinasi tinggi, kuat dalam tantangan, berani mengambil resiko, kelenturan berpikir, kepercayaan diri sendiri, dan kemandirian yang dikemas dalam bentuk kuesioner

4. Sikap Optimis adalah skor yang diperoleh dari mahasiswa PG PAUD Universitas Terbuka di UPBJJ Makassar berupa: pemilikikan sasaran hidup yang jelas, penciptaan opini diri yang kuat, pemilikan sikap, pemilikan pandangan yang sehat tentang hidup ini, penemuan orang yang bisa mengispirasi diri, peningkatan keimanan, penambahan modal hidup, dan kesiapan pencerahan hidup setiap saat yang dikemas dalam bentuk kuesioner.

\section{Populasi dan Sampel Penelitian}

Populasi penelitian ini adalah mahasiswa PG PAUD UT UPBJJ Makassar yang mengambil MK PAUD4505 pada semester 9 sebanyak 180. Sampel penelitian 119 orang. Penetapan sampel digunakan table ISAAC dan Michael dari populasi tertentu dengan taraf kesalahan $5 \%$. Teknik sampling yang digunakan adalah teknik purporsive sampling (Sugiyono, 2010: 128).

Untuk lebih jelasnya data sampel dapat dilihat dalam tabel berikut.

Tabel 1. Sampel Penelitian

\begin{tabular}{clc}
\hline No. & \multicolumn{1}{c}{ Nama Kabupaten } & Jumlah Sampel \\
\hline 1 & Jeneponto & 28 \\
2 & Maros & 10 \\
3 & Palopo & 26 \\
4 & Bulukumba & 15 \\
5 & Wajo & 20 \\
6 & Sidrap & 20 \\
\hline & Jumlah & 119 \\
\hline
\end{tabular}

\section{Teknik Pengumpulan Data}

Teknik pengumpulan data yang digunakan dalam penelitian ini adalah teknik kuesioener dan teknik dokumentasi nilai. Teknik kuesioner dimaksudkan mendapatkan data tentang sikap positif, kreatif dan optimistis, sedangkan teknik dokumentasi dimaksudkan mendapatkan data skor kumulatif mata kuliah PAUD4504.

\section{Teknik Analisis Data}

Penelitian ini menggunakan teknik analisis data regresi linear untuk korelasi masing-masing variabel bebas terhadap variabel terikat dengan rumus sebagai berikut.

Keterangan:

$$
\hat{\mathrm{Y}}=\mathrm{a}+\mathrm{bX}
$$

$\hat{Y}=$ subjek dalam variable terikat yang diprediksikan

$\mathrm{a}=$ harga $\mathrm{Y}$ ketika harga $\mathrm{X}=0$ (harga konstan) $\mathrm{b}=$ koefisien regresi

$\mathrm{x}=$ subjek pada variable bebas

Menghitung koefisien korelasi sederhana dan uji keberartian regresi sederhana menggunakan rumus koefisien sederhana sebagai berikut (Sugiyono,2012):

$$
r_{x y}=\frac{N \sum X Y-\left(\sum X\right)\left(\sum Y\right)}{\sqrt{\left[N \sum X^{2}-\left(\sum X\right)^{2}\right]\left[N \sum Y^{2}-\left(\sum Y\right)^{2}\right]}}
$$

Keterangan:

$r_{x y}=$ nilai korelasi product moment

$\mathrm{X}=$ skor yang diperoleh setiap subjek untuk variabel $X$

$\mathrm{Y}=$ skor yang diperoleh setiap subjek untuk variabel $Y$

$\mathrm{N}$ = jumlah subjek 


\section{HASIL DAN PEMBAHASAN}

Bagian ini terdiri dari (a) uji hasil validitas,, (b) uji hasil reliabilitas kuesioner penelitian, (c) pengujian hipotesis, dan (d) pembahasan hasil penelitian.

\section{Uji Validitas Kuesioner}

Untuk menguji apakah instrumen yang digunakan memenuhi persyaratan validitas digunakan korelasi Pearson. Cara analisisnya dengan cara menghitung koefisien korelasi antara masing-masing nilai pada nomor pertanyaan dengan nilai total dari nomor pertanyaan tersebut. Selanjutnya koefisien korelasi yang diperoleh $\mathrm{r}$ masih harus diuji signifikansinya bisa menggunakan uji $\mathrm{t}$ atau membandingkannya dengan $r$ tabel. Bila $t$ hitung > dari t tabel atau $\mathrm{r}$ hitung $>$ dari $\mathrm{r}$ tabel, maka nomor pertanyaan tersebut valid. Bila menggunakan program komputer, asalkan $r$ yang diperoleh diikuti harga $\mathrm{p}<0,05$ berarti nomor pertanyaan itu valid (Sanusi, 2010). Dari hasil perhitungan menggunakan SPSS 22, terdapat 11 indikator yang tidak valid yaitu indikator No. 1, No. 9 dan N0. 14 dari variabel Sikap Positif, indikator No. 28, No. 31, No. 38, No. 40, No. 43, No. 47 dari variabel Sikap Optimis, No. 62 dan No. 72 dari variabel Sikap Kreatif. Seluruh indikator yang tidak valid tersebut kemudian dihapus dari daftar pertanyaan sebelum masuk ke uji reliabilitas.

Uji Reliabilitas

Uji reliabilitas (keandalan) instrumen dilakukan dengan teknik alpha Cronbach dengan kriteria reliabilitas suatu konstruk variabel dinyatakan baik jika memiliki nilai Cronbach's Alpha > 0,60 (Santoso, 2018). Berdasarkan hasil perhitungan menggunakan SPSS 22, hasil reliabilitas yang diperoleh dapat dilihat pada Tabel 1.

\section{Reliability Statistics}

Tabel 2. Hasil Uji Reliabilitas

$\frac{\text { Cronbach's Alpha }}{.853}$

Berdasarkan hasil perhitungan pada Tabel 1 diatas, dapat dilihat nilai Cronbach's Alpha $(\alpha)$ diperoleh 0,853, maka dapat disimpulkan bahwa hasil reliabilitas dinyatakan "Baik".

\section{Pengujian Hipotesis}

Pengujian hipotesis yang diajukan dimaksudkan untuk mengetahui penarikan hipotesis nol (Ho) yang dilakukan ditolak dan menerima hipotesis alternatif $\left(\mathrm{H}_{1}\right)$ atau sebaliknya. Untuk itu, dilakukan pengujian hipotesis, yaitu (1) hipotesis pertama, kedua, ketiga diuji dengan teknik analisis regresi sederhana dan (2) pengujian hipotesis keempat dengan teknik analisis regresi ganda. Hasil pengujian pertama, kedua, ketiga dan keempat hipotesis tersebut dapat dideskripsikan sebagai baerikut.

Tabel 3. Model Summary

\begin{tabular}{ccccc}
\hline Model & $\mathrm{R}$ & $\mathrm{R}$ Square & Adjusted R Square & Std. Error of the Estimate \\
\hline 1 & $.629^{\mathrm{a}}$ & .396 & .391 & 9.24174 \\
\hline Predictors: (Constant), SIKAP POSITIF & &
\end{tabular}

Analisis korelasi sederhana terhadap sikap positif $\left(\mathrm{X}_{1}\right)$ dengan prestasi belajar mata kuliah PAUD4504 (Y) menunjukkan bahwa koefisien korelasi $\mathbf{r}_{\mathbf{y}}{ }^{1}$ sebesar $0,629^{a}$. Hasil pengujian keberartian koefisien korelasi dengan menggunakan uji t diperoleh bahwa $t_{\text {hitung }} 8.754$ signifikan pada taraf 0,000 . Hal ini berarti bahwa pengaruh antara sikap positif $\left(\mathrm{X}_{1}\right)$ dengan prestasi belajar mata kuliah PAUD4504 (Y) mahasiswa PG PAUD di UPBJJ UT Makassar adalah signifikan. 
Tabel 4. Coefficients ${ }^{\mathrm{a}}$

\begin{tabular}{|c|c|c|c|c|c|c|}
\hline \multirow[t]{2}{*}{ Model } & & \multicolumn{2}{|c|}{$\begin{array}{c}\text { Unstandardized } \\
\text { Coefficients }\end{array}$} & \multirow{2}{*}{$\begin{array}{c}\begin{array}{c}\text { Standardized } \\
\text { Coefficients }\end{array} \\
\text { Beta }\end{array}$} & \multirow[t]{2}{*}{$\mathrm{t}$} & \multirow[t]{2}{*}{ Sig. } \\
\hline & & B & Std. Error & & & \\
\hline & (Constant) & 31.410 & 2.940 & & 10.683 & .000 \\
\hline 1 & $\begin{array}{l}\text { SIKAP } \\
\text { POSITIF }\end{array}$ & .409 & .047 & .629 & 8.754 & .000 \\
\hline
\end{tabular}

Dependent Variable: PRESTASI BELAJAR

Analisis regresi sederhana terhadap data skor mata kuliah PAUD4504 dan data skor sikap positif menghasilkan konstanta " $\alpha$ " sebesar 31,410 dan koefisien regresi " $\mathrm{b}$ " sebesar 0,409 sehingga persamaan regresinya $\hat{\mathrm{Y}}=$ $31,410+0,409 X_{1}$. Pengujian keberartian koefisien regresi antara sikap positi $\left(\mathrm{X}_{1}\right)$ dengan prestasi belajar belajar mata muliah PAUD4504 (Y). Dengan demikikan dapat disimpulkan bahwa regresi dengan persamaan regresi $\hat{Y}=$ 31,410+ 0,409X1 adalah signifikan.

Persamaan regresi $\hat{Y}=31,410+0,409 X 1$ menunjukkan bahwa, setiap kenaikan satu skor pada sikap positif $\left(\mathrm{X}_{1}\right)$ menyebabkan kenaikan sebesar 0,409 skor prestasi belajar belajar mata kuliah PAUD4504 (Y) pada konstanta 31,410. Korelasi positif antara sikap positif $\left(\mathrm{X}_{1}\right)$ dengan prestasi belajar belajar mata kuliah PAUD4504 (Y) didukung oleh koefisien determinasi sebesar $\mathrm{r}_{\mathrm{y} 1}{ }^{2}=0,396$. Hal ini berarti bahwa $39,6 \%$ variasi yang terjadi pada prestasi belajar belajar mata kuliah PAUD4504 (Y) dapat dijelaskan oleh variasi sikap positif $\left(\mathrm{X}_{1}\right)$ melalui persamaan regreasi $\hat{Y}=31,410+0,409 \mathrm{X}_{1}$. Oleh karena nilai signifikansi (Sig) sebesar 0,000 lebih kecil dari probabilitas 0,05 sehingga dapat disimpulkan bahwa Ha diterima yang berarti bahwa antara sikap positif $\left(\mathrm{X}_{1}\right)$ dengan prestasi belajar mata kuliah PAUD4504 mempunyai pengaruh positif yang signifikan.

\section{Terdapat pengaruh positif yang signifikan antara sikap optimis $\left(\mathrm{X}_{2}\right)$ dengan Prestasi Belajar Mata Kuliah PAUD4504 (Y) Mahasiswa PG PAUD di UPBJJ UT Makassar.}

Hipotesis kedua yang diajukan "Terdapat pengaruh positif yang signifikan antara sikap optimis $\left(\mathrm{X}_{2}\right)$ dengan prestasi belajar mata muliah PAUD4504 (Y) mahasiswa PG PAUD di UPBJJ UT Makassar. Hipotesis statistikanya adalah sebagai berikut.

Ho = tidak ada pengaruh $\mathrm{X}_{1}$ dengan $\mathrm{Y}$ (nilai sig $>$ dari nilai probabilitas 0,05 )

$\mathrm{Ha}=$ ada pengaruh $\mathrm{X}$ dengan $\mathrm{Y}$ (nilai sig $<$ dari nilai probabilitas 0,05

Tabel 5. Model Summary

\begin{tabular}{ccccc}
\hline Model & $\mathrm{R}$ & R Square & Adjusted R Square & $\begin{array}{c}\text { Std. Error of the } \\
\text { Estimate }\end{array}$ \\
\hline 1 & $.607^{\mathrm{a}}$ & .368 & .362 & 9.45287 \\
\hline
\end{tabular}

Predictors: (Constant), SIKAP OPTIMIS

Analisis korelasi sederhana terhadap relevansi antara sikap optimis $\left(\mathrm{X}_{1}\right)$ dengan prestasi belajar mata kuliah PAUD4504 (Y) menunjukkan bahwa koefisien korelasi $\mathbf{r}_{\mathbf{y}}{ }^{1}$ sebesar $0,607^{\mathrm{a}}$. Hasil pengujian keberartian koefisien korelasi dengan menggunakan uji t diperoleh bahwa $t_{\text {hitung }} 8.251$ signifikan pada taraf 0,000 . Hal ini berarti bahwa pengaruh antara sikap optimis $\left(\mathrm{X}_{2}\right)$ dengan prestasi pelajar mata kuliah PAUD4504 (Y) Mahasiswa PG PAUD di UPBJJ UT Makassar adalah signifikan.

Tabel 6. Coefficients ${ }^{\mathrm{a}}$

\begin{tabular}{|c|c|c|c|c|c|c|}
\hline \multirow[t]{2}{*}{ Model } & & \multicolumn{2}{|c|}{ Unstandardized Coefficients } & \multirow{2}{*}{$\begin{array}{l}\text { Standardized } \\
\text { Coefficients } \\
\text { Beta }\end{array}$} & \multirow[t]{2}{*}{$\mathrm{t}$} & \multirow[t]{2}{*}{ Sig. } \\
\hline & & $\mathrm{B}$ & Std. Error & & & \\
\hline & (Constant) & 32.971 & 2.929 & & 11.256 & .000 \\
\hline 1 & $\begin{array}{l}\text { SIKAP } \\
\text { OPTIMIS }\end{array}$ & .399 & .048 & .607 & 8.251 & .000 \\
\hline
\end{tabular}

Dependent Variable: PRESTASI BELAJAR 
Analisis regresi sederhana terhadap data skor mata kuliah PAUD4504 dan data skor sikap optimis menghasilkan konstanta " $\alpha$ " sebesar 32,971 dan koefisien regresi " $\mathrm{b}$ " sebesar 0,399 sehingga persamaan regresinya $\hat{Y}=32,971+$ $0,399 \mathrm{X}_{2}$. Pengujian keberartian koefisien regresi antara sikap optimis $\left(\mathrm{X}_{2}\right)$ dengan prestasi belajar mata kuliah PAUD4504 (Y). Dengan demikikan dapat disimpulkan bahwa regresi dengan persamaan regresi $\hat{Y}=32,971+$ $0,399 X_{2}$ adalah signifikan.

Persamaan regresi $\hat{Y}=32,971+$ $0,399 \mathrm{X}_{2}$ menunjukkan bahwa, setiap kenaikan satu skor pada sikap optimis $\left(\mathrm{X}_{2}\right)$ menyebabkan kenaikan sebesar 0,399 skor prestasi belajar mata kuliah PAUD4504 (Y) pada konstanta 31,410. Korelasi positif antara sikap optimis $\left(\mathrm{X}_{2}\right)$ dengan prestasi belajar mata kuliah PAUD4504 (Y) didukung oleh koefisien determinasi sebesar $r_{y 1}{ }^{2}=0,368$. Hal ini berarti bahwa $36,8 \%$ variasi yang terjadi pada prestasi belajar mata kuliah PAUD4504 (Y) dapat dijelaskan oleh variasi sikap optimis $\left(\mathrm{X}_{2}\right)$ melalui persamaan regreasi $\hat{Y}=.32,971+$ $0,399 \mathrm{X}_{2}$. Oleh karena nilai signifikansi (Sig) sebesar 0,000 lebih kecil dari probabilitas 0,05 sehingga dapat disimpulkan bahwa Ha diterima yang berarti bahwa antara sikap optimis $\left(\mathrm{X}_{2}\right)$ dengan prestasi belajar mata kuliah PAUD4504 mempunyai pengaruh positif yang signifikan.

\section{Terdapat pengaruh positif yang signifikan antara sikap kreatif $\left(\mathrm{X}_{3}\right)$ dengan Prestasi Belajar Mata Kuliah PAUD4504 (Y) Mahasiswa PG PAUD di UPBJJ UT Makassar.}

Hipotesis ketiga yang diajukan "Terdapat pengaruh positif yang signifikan antara sikap kreatif $\left(\mathrm{X}_{3}\right)$ dengan prestasi belajar mata kuliah PAUD4504 (Y) mahasiswa PG PAUD di UPBJJ UT Makassar. Hipotesis statistikanya adalah sebagai berikut.

Ho = tidak ada pengaruh $\mathrm{X}_{1}$ dengan $\mathrm{Y}$ (nilai sig $>$ dari nilai probabilitas 0,05 )

$\mathrm{Ha}=$ ada pengaruh $\mathrm{X}$ dengan $\mathrm{Y}$ (nilai sig $<$ dari nilai probabilitas 0,05 )

Model 7. Model Summary

\begin{tabular}{lrrrr}
\hline Model & R & R Square & Adjusted R Square & Std. Error of the Estimate \\
\hline 1 & $.589^{\mathrm{a}}$ & .346 & .341 & 9.61216 \\
\hline Predictors: (Constant), SIKAP KREATIF & &
\end{tabular}

Analisis korelasi sederhana terhadap antara sikap kreatif $\left(\mathrm{X}_{3}\right)$ dengan prestasi belajar mata kuliah PAUD4504 (Y) menunjukkan bahwa koefisien korelasi $\mathbf{r}_{\mathbf{y}}{ }^{1}$ sebesar $0,589^{\mathrm{a}}$. Hasil pengujian keberartian koefisien korelasi dengan menggunakan uji t diperoleh bahwa thitung 7.784 signifikan pada taraf 0,000 . Hal ini berarti bahwa pengaruh antara sikap kreatif $\left(\mathrm{X}_{3}\right)$ dengan prestasi belajar mata kuliah PAUD4504 (Y) Mahasiswa PG PAUD di UPBJJ UT Makassar adalah signifikan.

Tabel 8. Coefficients ${ }^{\mathrm{a}}$

\begin{tabular}{|c|c|c|c|c|c|c|}
\hline \multirow[t]{2}{*}{ Model } & & \multicolumn{2}{|c|}{ Unstandardized Coefficients } & \multirow{2}{*}{$\begin{array}{l}\text { Standardized } \\
\text { Coefficients } \\
\text { Beta }\end{array}$} & \multirow[t]{2}{*}{$\mathrm{t}$} & \multirow[t]{2}{*}{ Sig. } \\
\hline & & B & Std. Error & & & \\
\hline & (Constant) & 22.508 & 4.351 & & 5.173 & .000 \\
\hline 1 & $\begin{array}{l}\text { SIKAP } \\
\text { KREATIF }\end{array}$ & .606 & .077 & .589 & 7.874 & .000 \\
\hline
\end{tabular}

Dependent Variable: PRESTASI BELAJAR

Analisis regresi sederhana terhadap data skor mata kuliah PAUD4504 dan data skor sikap kreatif menghasilkan konstanta " $\alpha$ " sebesar 22,508 dan koefisien regresi " $b$ " sebesar 0,606 sehingga persamaan regresinya $\hat{\mathrm{Y}}=22,508+0,606 \mathrm{X}_{3}$. Pengujian keberartian koefisien regresi antara sikap kreatif $\left(\mathrm{X}_{3}\right)$ dengan prestasi belajar mata kuliah PAUD4504 (Y). Dengan demikikan dapat disimpulkan bahwa regresi dengan persamaan regresi $\hat{Y}=22,508+0,606 \mathrm{X} 3$ adalah signifikan.

Persamaan regresi $\hat{Y}=22,508+$ $0,606 \mathrm{X}_{3}$ menunjukkan bahwa, setiap kenaikan satu skor pada sikap kreatif $\left(\mathrm{X}_{3}\right)$ menyebabkan kenaikan sebesar 0,606 skor prestasi belajar mata kuliah PAUD4504 (Y) pada konstanta 31,410. Korelasi positif antara sikap kreatif $\left(\mathrm{X}_{3}\right)$ dengan prestasi belajar mata kuliah PAUD4504 (Y) didukung oleh koefisien 
determinasi sebesar $r_{y 1}{ }^{2}=0,346$. Hal ini berarti bahwa $34,6 \%$ variasi yang terjadi pada prestasi belajar mata kuliah PAUD4504 (Y) dapat dijelaskan oleh variasi sikap kreatif $\left(\mathrm{X}_{3}\right)$ melalui persamaan regreasi $\hat{Y}=32,971+$ $0,399 X_{3}$. Oleh karena nilai signifikansi (Sig) sebesar 0,000 lebih kecil dari probabilitas 0,05 sehingga dapat disimpulkan bahwa Ha diterima yang berarti bahwa antara sikap kreatif $\left(\mathrm{X}_{3}\right)$ dengan prestasi belajar mata kuliah PAUD4504 mempunyai pengaruh positif yang signifikan.

4. Terdapat pengaruh positif yang signifikan antara keseluruhan variabel bebas $\left(X_{1}, X_{2}, X_{3}\right)$ dengan Prestasi

\section{Belajar Mata Kuliah PAUD4504 (Y) Mahasiswa PG PAUD di UPBJJ UT Makassar.}

Hipotesis keempat yang diajukan "Terdapat pengaruh positif yang signifikan antara keseluruhan variabel bebas $\left(\mathrm{X}_{1}, \mathrm{X}_{2}, \mathrm{X}_{3}\right)$ dengan Prestasi Belajar Mata Kuliah PAUD4504 (Y) Mahasiswa PG PAUD di UPBJJ UT Makassar. Hipotesis statistikanya adalah sebagai berikut.

Ho = tidak ada pengaruh $\mathrm{X}_{1}$ dengan $\mathrm{Y}$ (nilai sig > dari nilai probabilitas 0,05 )

$\mathrm{Ha}=$ ada pengaruh $\mathrm{X}$ dengan $\mathrm{Y}$ (nilai sig < dari nilai probabilitas 0,05 ).

Tabel 9. Model Summary

\begin{tabular}{lrrrr}
\hline Model & R & R Square & Adjusted R Square & Std. Error of the Estimate \\
\hline 1 & $.725^{\mathrm{a}}$ & .526 & .514 & 8.25595 \\
\hline
\end{tabular}

Predictors: (Constant), SIKAP KREATIF, SIKAP OPTIMIS, SIKAP POSITIF

Dari tabel model summary diketahui besarnya korelasi $(\mathrm{R})$, koefisien determinasi $\left(\mathrm{R}^{2}\right)$, koefisien determinasi yang disesuaikan Adjusted R Square dan standar error.Koefisien korelasi (R) sebesar 0,725 , mendekati nilai 1 . Artinya, pengaruh antara variabel-variabel bebas $\left(\mathrm{X}_{1}, \mathrm{X}_{2}\right.$, dan $\left.\mathrm{X}_{3}\right)$ dengan varibel terikat (Y) sangat kuat. Pengaruh antara variabel bebas $\left(\mathrm{X}_{1}, \mathrm{X}_{2}\right.$, dan $\left.\mathrm{X}_{3}\right)$ dengan variable terikat

(Y) bersifat positif. Artinya, jika nilai X naik, maka akan direspon dengan kenaikan nilai $\mathrm{Y}$. Koefisien determinasi $\left(\mathrm{R}^{2}\right)$ sebesar 0,526, artinya bahwa $52,6 \%$ prestasi belajar mata kuliah PAUD4504 dipengaruhi oleh faktor sikap positif, optimisme, dan sikap kreatif. Sedangkan 47,4\% (100\%-52,6\%) karena faktor lain yang tidak dapat dijelaskan dalam persamaan regresi.

Tabel 10. Coefficients ${ }^{\mathrm{a}}$

\begin{tabular}{|c|c|c|c|c|c|c|}
\hline \multirow[t]{2}{*}{ Model } & & \multicolumn{2}{|c|}{ Unstandardized Coefficients } & \multirow{2}{*}{$\begin{array}{c}\text { Standardized } \\
\text { Coefficients } \\
\text { Beta }\end{array}$} & \multirow[t]{2}{*}{$\mathrm{t}$} & \multirow[t]{2}{*}{ Sig. } \\
\hline & & $\mathrm{B}$ & Std. Error & & & \\
\hline \multirow{4}{*}{1} & (Constant) & 18.330 & 3.791 & & 4.836 & .000 \\
\hline & SIKAP POSITIF & .214 & .055 & .328 & 3.915 & .000 \\
\hline & $\begin{array}{l}\text { SIKAP } \\
\text { OPTIMIS }\end{array}$ & .194 & .054 & .294 & 3.601 & .000 \\
\hline & $\begin{array}{l}\text { SIKAP } \\
\text { KREATIF }\end{array}$ & .247 & .086 & .240 & 2.884 & .005 \\
\hline
\end{tabular}

Dependent Variable: PRESTASI BELAJAR

Sesuai dengan tabel coefficients ${ }^{\mathrm{a}}$ diketahui persamaan regresi $\mathrm{Y}=18.330+$ $0.214 \mathrm{X}_{1},+0.194 \mathrm{X}_{2}+0.247 \mathrm{X}_{3}$. Dari persamaan dapat dijelaskan bahwa konstanta (a) $=18.330$. Artinya, sikap positif, sikap optimis, dan sikap kreatif adalah faktor penentu prestasi belajar mata kuliah PAUD4504 mahasiswa mahasiswa PG PAUD di UPBJJ UT Makassar. Koefisien regresi $=0.214, \quad X_{1}=0.194, X_{2}=0.247 X_{3}$. Artinya, jika siakp positif, sikap optimis, dan sikap kreatif adalah faktor penentu peningkatan kualitas prestasi belajar mata kuliah PAUD4504, maka kualitas prestasi belajar semakin meningkat.

Berdasarkan hasil pengujian statistik dapat diambil keputusan, yaitu menolak hipotesis nol $\left(\mathrm{H}_{0}\right)$, dan menerima hipotesis alternatif (Ha). Dengan demikian, hipotesis penelitian yang diajukan, yaitu terdapat pengaruh positif yang signifikan antara sikap positif, optimis, dan sikap kreatif dengan prestasi belajar mata kuliah PAUD4504 (Y) 
mahasiswa PG PAUD di UPBJJ UT Makassar telah teruji kebenarannya.

\section{HASIL DAN PEMBAHASAN}

1. Hipotesis pertama yang diajukan "Terdapat pengaruh positif yang signifikan antara sikap positif $\left(\mathbf{X}_{1}\right)$ dengan Prestasi Belajar Mata Kuliah PAUD4504 (Y) Mahasiswa PG PAUD di UPBJJ UT Makassar.

Hasil analisis data dapat diketahui bahwa koefisien korelasi sikap positif dengan prestasi belajar mata kuliah PAUD4504 (Y) mahasiswa PG PAUD di UPBJJ UT Makassar sebesar $0,629^{a}$ dengan signifikansi $0,000 \%$. Hal ini menunjukkan bahwa sikap positif mempunyai korelasi positif yang signifikan dengan prestasi belajar mata kuliah PAUD4504 (Y) mahasiswa PG PAUD di UPBJJ UT Makassar. Hasil temuan ini menunjukkan bahwa sikap positif meliputi: penguatan cara pandang, karena pengaruh orang lain, karena momentum tertentu, ketika menghadapi kesulitan, selalu berpikir positif, muatan, penggunaan, dan pengawasan pikiran positif, Formula 3C catch, change, dan create, dan menjadikan kehidupan selalu konstruktif dan produktif mempunyai pengaruh positif yang signifikan dalam peningkatan prestasi belajar mata kuliah PAUD4504 (Y) mahasiswa PG PAUD di UPBJJ UT Makassar. Hasil penelitian terkait dengan sikap positif dengan prestasi belajar,yakni hasil penelitian Yuan Andinny (2015) berpikir atau bersikap positif berpengaruh terhadap prestasi belajarn matematika, Syamsu Rijal Suhaedir Bachtiar (2015) sikap positif siswa berhubungan dengan hasil belajar kognitif Biologi.

2. Hipotesis kedua yang diajukan "Terdapat pengaruh positif yang signifikan antara sikap optimis $\left(\mathbf{X}_{2}\right)$ dengan Prestasi Belajar Mata Kuliah PAUD4504 (Y) Mahasiswa PG PAUD di UPBJJ UT Makassar.

Hasil analisis data dapat diketahui bahwa koefisien korelasi sikap optimis dengan prestasi belajar mata kuliah PAUD4504 (Y) mahasiswa PG PAUD di UPBJJ UT Makassar sebesar $0,607^{\mathrm{a}}$ dengan signifikansi $0,000 \%$. Hal ini menunjukkan bahwa sikap positif mempunyai korelasi positif yang signifikan dengan prestasi belajar mata kuliah PAUD4504 (Y) mahasiswa PG PAUD di
UPBJJ UT Makassar. Hasil temuan ini menunjukkan bahwa sikap optimis meliputi: mengejar hari esok lebih baik, menyalurkan energi positif, perlawanan, unsur penunjang, memiliki sasaran hidup yang jelas, ciptakan opini diri yang kuat, miliki sikap dan pandangan yang sehat tentang hidup ini, temukan orang yang bisa mengispirasi diri, Tingkatkan keimanan, tambahlah modal hidup, dan buka pintu pencerahan mempunyai pengaruh positif yang signifikan dalam peningkatan prestasi belajar mata kuliah PAUD4504 (Y) mahasiswa PG PAUD di UPBJJ UT Makassar.

3. Hipotesis ketiga yang diajukan "Terdapat pengaruh positif yang signifikan antara sikap kreatif $\left(X_{3}\right)$ dengan Prestasi Belajar Mata Kuliah PAUD4504 (Y) Mahasiswa PG PAUD di UPBJJ UT Makassar.

Hasil analisis data dapat diketahui bahwa koefisien korelasi sikap kreatif dengan prestasi belajar mata kuliah PAUD4504 (Y) mahasiswa PG PAUD di UPBJJ UT Makassar sebesar $0,589^{\mathrm{a}}$ dengan signifikansi $0,000 \%$. Hal ini menunjukkan bahwa sikap kreatif mempunyai korelasi positif yang signifikan dengan prestasi belajar mata kuliah PAUD4504 (Y) mahasiswa PG PAUD di UPBJJ UT Makassar. Hasil temuan ini menunjukkan bahwa sikap kreatif meliputi: keterbukaan terhadap pengalaman baru, kelenturan dalam berpikir, kebebasan dalam ungkapan diri, menghargai fantasi, minat terhadap kegiatan kreatif, mepercayaan terhadap gagasan sendiri, memandirian dalam memberi pertimbangan mempunyai pengaruh positif yang signifikan dalam peningkatan prestasi belajar mata kuliah PAUD4504 (Y) mahasiswa PG PAUD di UPBJJ UT Makassar.

4. Terdapat pengaruh positif yang signifikan antara keseluruhan variabel bebas $\left(\mathbf{X}_{1}, \mathbf{X}_{2}, \mathbf{X}_{3}\right)$ dengan Prestasi Belajar Mata Kuliah PAUD4504 (Y) Mahasiswa PG PAUD di UPBJJ UT Makassar.

Hasil analisis data dapat diketahui bahwa koefisien korelasi antara keseluruhan variabel bebas $\left(\mathrm{X}_{1}, \mathrm{X}_{2}, \mathrm{X}_{3}\right)$ dengan Prestasi Belajar Mata Kuliah PAUD4504 (Y) Mahasiswa PG PAUD di UPBJJ UT Makassar sebesar 0,725 dengan signifikansi 
0,000\%. Hal ini menunjukkan bahwa pengaruh antara variabel-variabel bebas $\left(\mathrm{X}_{1}, \mathrm{X}_{2}\right.$, dan $\left.\mathrm{X}_{3}\right)$ dengan varibel terikat $(\mathrm{Y})$ sangat kuat. Pengaruh antara variable terikat $\left(\mathrm{X}_{1}, \mathrm{X}_{2}\right.$, dan $\left.\mathrm{X}_{3}\right)$ dengan variable terikat $(\mathrm{Y})$ bersifat positif. Artinya, jika nilai $\mathrm{X}_{1}, \mathrm{X}_{2}$, dan $\left.\mathrm{X}_{3}\right)$ naik, maka akan direspon dengan kenaikan nilai $\mathrm{Y}$. Koefisien determinasi $\left(\mathrm{R}^{2}\right)$ sebesar 0,526 , artinya bahwa $52,6 \%$ prestasi belajar mahasiswa dipengaruhi oleh faktor sikap positif, optimis, dan sikap kreatif. Sedangkan 47,4\% (100\%-52,6\%) karena faktor lain yang tidak dapat dijelaskan dalam persamaan regresi.

Dengan demikian aspek sikap positif $\left(\mathrm{X}_{1}\right)$, optimis $\left(\mathrm{X}_{2}\right)$, dan sikap kreatif $\left(\mathrm{X}_{3}\right)$ dapat menjadi acuan untuk meningkatkan prestasi belajar mata kuliah PAUD4504 (Y) mahasiswa PG PAUD di UPBJJ UT Makassar.

\section{KESIMPULAN DAN SARAN Kesimpulan} berikut.

Kesimpulan hasil penelitian sebagai

1. Terdapat pengaruh positif yang signifikan antara sikap positif $\left(\mathrm{X}_{1}\right)$ dengan prestasi belajar mata kuliah PAUD4504 (Y) mahasiswa PG PAUD di UPBJJ UT Makassar.dengan koefisien korelasi )R) 0,629 dan krelasi determinasi $\left(\mathbf{R}^{2}\right)$ 0,39,6 atau $39,6 \%$.

2. Terdapat pengaruh positif yang signifikan antara sikap optimis $\left(\mathrm{X}_{2}\right)$ dengan prestasi belajar mata kuliah PAUD4504 (Y) mahasiswa PG PAUD di UPBJJ UT Makassar.dengan koefisien korelasi )R) 0,607 dan krelasi determinasi $\left(\mathrm{R}^{2}\right)$ 0,36,8 atau $36,8 \%$.

3. Terdapat pengaruh positif yang signifikan antara sikap kreatif $\left(\mathrm{X}_{3}\right)$ dengan prestasi belajar mata kuliah PAUD4504 (Y) mahasiswa PG PAUD di UPBJJ UT Makassar.dengan koefisien korelasi (R) 0,589 dan krelasi determinasi $\left(R^{2}\right) \quad 0,346$ atau $34,6 \%$.

4. Terdapat pengaruh positif yang signifikan antara keseluruhan variabel bebas $\left(\mathrm{X}_{1}\right.$, $\mathrm{X}_{2}, \mathrm{X}_{3}$ ) dengan Prestasi Belajar Mata Kuliah PAUD4504 (Y) Mahasiswa PG PAUD di UPBJJ UT Makassar dengan koefisien korelasi )R) 0,752 dan korelasi determinasi $\left(\mathrm{R}^{2}\right) 526$ atau 52,6\%.
Berdasarkan simpulan dan pembahasan penelitian ini, ada beberapa saran yang perlu disampaikan terkait dengan penelitian ini sebagai berikut.

1. Hasil penelitian ini sebaiknya dijadikan salah satu materi ketika OSMB dan pembekalan tutor di UPBJJ UT Makassar atau di Kabupaten dan kota

2. Hasil penelitian ini sebaiknya dijadikan materi penguatan tutor kepada mahasiswa untuk peningkatan kualitas prestasi belajar

3. Sebagai bahan inspirasi penelitian lanjutan dengan fokus masalah lebih komples dan area yang lebih luas.

\section{DAFTAR RUJUKAN}

Ananta Z. (2014). Kebiasaan-Kebiasaan Unik Orang Sukses \& Kaya Raya, Yogyakarta: Citra Risalah

Arifin Z. ( 2009). Evaluasi Pembelajaran Prinsip Teknik Prosedur. Bandung: PT. Remaja Rosdakarya.

Alex Sobur, (2003). Psikologi Umum, Bandung: Pustaka Setia

Awang S. (2018). Mindsets for Success, Jakarta: PT Alex Media Komputindo

Ahmadi A., dan Widodo S. (2004) . Psikologi Belajar. Cetakan ke-2. Jakarta: Rineka Cipta.

Beetleston, F. 2011. Creative Learning. Bandung: Nusa Media.

Bungin, B. (2005). Metodologi Penelitian Kuantitatif, Komunikasi, Ekonomi, Kebijakan Publik, dan Ilmu-Ilmu Sosial Lainnya, Jakarta: Kencana Pernada Media Group

Dahlan S. (2008). Seribu Pena Pendidikan Kewarganegaraan untuk SMP/MTs Kelas IX, Jakarta: Erlangga

Elfiky I. (2009). Terapi Berpikir Positif, Jakarta: PT Serambi Ilmu Semesta

Farida N. (2014). Pengaruh Sikap kreatif Terhadap Prestasi Belajar Matematika. Aksioma. Jurnal Pendidikan Matematika FKIP

Fitriyan Dennis. 2009. Berpikir Kreatif. Jakarta: Esensi.

Hamalik O. (2002). Psikologi Belajar dan Mengajar, Jakarta: Bina Aksara Citra

Hartati L. (2013). Pengaruh Gaya Belajar dan Sikap Siswa pada Pelajaran Matematika Terhadap Hasil Belajar Matematika. Jurnal Formatif 3 (3): 224-235, Vol 3 No. 
3, ISSN: 2088-351X. Fak. Teknik, Matematika \& IPA Universitas Indraprasta PGRI

Kurniati L. \& AU Fahruddin (2018). Pengaruh Optimisme Terhadap Kemampuan Pemecahan Masalah matematika pada Siswa SMA, Prociding Seminar \& Internasional

Kotler, Philip dan Gary Amstrong (2008). Dasar-Dasar Pemasaran, Edisi Ke-9 Jilid 1, Jakarta:

PT Indeks Kelompok Gramedia

Maemunah, M., Herman, H., \& Rahmatullah, R. (2018). Kecerdasan Emosional Dan Berfikir Logis Pengaruhnya Terhadap Hasil Belajar Ekonomi. JEKPEND: Jurnal Ekonomi Dan Pendidikan, 1(2), 66. https://doi.org/10.26858/jekpend.v1i2.72 54

Monty PS.\& Fidalis EW. (2003). Mendidik Kecerdasan, Jakarta: Media Grafik

Nasution, S. (1996). Didaktik Asas-Asas Mengajar, Bandung: Jemnars

Nugroho D (2017). 50 Karakter dan Kepribadian Orang Berbakat Kaya Sejaka Muda, Yogyakarta: Araska

Peng Kheng Sun, (2013). Cara Kreatif Mengatasi Kejenuhan Bekerja, Jakarta: PT Gramedia Pustaka Utama

Poerwanto, Ngalim. (2007).Psikologi Pendidikan. Bandung: PT Rosda Karya

Quilliam S.(2007). Positive Thinking, Jakarta: Dian Rakyat.

Santoso, S. (2018). Mahir Statistik Multivariat dengan SPSS. Elex Media Komputindo.

Sanusi, S. R. (2010). Beberapa Uji Validitas dan Reliabilitas Pada Instrumen Penelitian. Retrieved from http://repository.usu.ac.id/handle/123456 $789 / 18868$

Sudijono A. (2008). Pengantar Evaluasi Pendidikan, Jakarta: PT Raja Grafindo Persada

Sugiyono (2010). Statistika Untuk Penelitian, Bandung: Alfabeta (2010). Metodologi Penelitian

Pendidikan Pendekatan Kualitatif, Kuantitatif, dan R\&D. Bandung: Alfabeta

(2012). Metode Penelitian

Pendidikan, Pendekatan Kuantitatif, Kualitatif, dan R\&D. Bandung: Alfabeta.

Saragi S. (2007). Menumbuh kembangkan Berpikir Logis dan Sikap Positif
Terhadap Matematika melalui pendekatan Matematika Holistik. Disertasi Tidak Terpublikasi, Bandung: UPI

Sia, Tjundjing. (2001). Hubungan Antara IQ, EQ, Dan QA Dengan Prestasi Studi Pada Siswa SMU. Jurnal Anima vol.17 No.1. 2001

Syamsu R. S.B. (2015). Hubungan antara Sikap, Kemandirian Belajar, dan Gaya Belajar dengan Hasil Belajar Kognitif Siswa. Jurnal BIOEDUKATIKA Vol. 3No. 2 Desember

Suharnan.( 2011). Kreativitas Teori dan Pengembangan. Surabaya: La

Sutikno, Sobri. (2004). Menggagas Pembelajaran Efektif Dan Bermakna. Mataram: NTP Press.

Ubaedy AN (2009). Kedahsyatan Berpikir Positif, Jakarta: PT Perspektif Momunika (2008). Ubah Sikap Raih

Kesuksesan, Jakarta: PT Perspektif Momunika (2008). Optimis Kunci Meraih Sukses, Jakarta: PT Perspektif Momunika

Utami M. (2009). Pengembangan Kreativitas Anak Berbakat. Jakarta: Rineka Cipta.

Uqshari Y. (2005). Percaya Diri Pasti, Jakarta: Gema Insani

Waskito (2013). The Power of Optimism: Membangun Harapan dan Semangat Umat Berdasarkan Al Quran, Sunnah dan Kehidupan Orang Shaleh, Jakarta: Pustaka Al Kautsar

Wardoyo S. (2010). Dahsyatnya Pikiran Positif, Yogyakarta: Manika Books Yuniarto B. (2018). Pandangan dan Sikap BEM UI Tehadap Jalan Reformasi, Yogyakarta: CV Budi Utama. 